\title{
StOchastic Optimal CONTROL MODELING OF DEBT CRISES
}

\author{
JEROME L. STEIN \\ CESIFO WORKING PAPER NO. 1043 \\ CATEGORY 6: MONETARY POLICY AND INTERNATIONAL FINANCE \\ SEPTEMBER 2003 \\ An electronic version of the paper may be downloaded \\ - from the SSRN website: www.SSRN.com \\ - from the CESifo website: www.CESifo.de
}




\title{
Stochastic Optimal Control Modeling OF DEBT CRISES
}

\begin{abstract}
What is an optimal or a sustainable external debt - for a country, region or sector? How should one monitor and evaluate debt to preclude a crisis? We use stochastic optimal control/dynamic programming to derive an optimal debt. The deviation of the actual from the optimal will serve as a Warning Signal of a crisis. There is a correspondence between Hamilton-Jacobi-Bellman equation of Dynamic Programming and the static Mean-Variance $(\mathrm{M}-\mathrm{V})$ analysis in finance. A graphic analysis of $\mathrm{M}-\mathrm{V}$ is helpful to explain the implications of DP. An explicit example is the US Agricultural debt crisis.
\end{abstract}

JEL Code: C61, D81, D9, F34.

Keywords: stochastic optimal control, debt, international finance, US agricultural crisis, Mean-Variance analysis, Hamilton-Jacobi-Bellaman equation.

\author{
Jerome L. Stein \\ Division of Applied Mathematics \\ Box $F$ \\ Brown University \\ Providence RI 02912 \\ U.S. A. \\ Jerome_Stein@Brown.edu
}

This paper was an invited lecture at the American Mathematical Society conference on Mathematical Finance, Snowbird, Utah June 2003. This paper is dedicated to the memory of James Tobin 1918-2002, teacher and friend. 


\section{Types of debt crises}

Debt crises have occurred in the South-East Asian, Latin American and African countries. Economies have borrowed either to finance government deficits, or investment/ capital formation as in South-East Asia. The debt, denominated in either domestic or foreign currency, may either be short-term that must be repaid with interest at maturity, or it may be long-term which just has to be serviced regularly. There are several sources of uncertainty, which may be positively or negatively correlated: the real return on capital and the variable real interest rate. Since it is not possible to predict either the return on capital or the interest rate, default has occurred frequently.

The issues discussed in this paper are as follows. (a) How much of a debt is too much? What is an optimal or a sustainable external debt - for a country, region or sector? (b) How should one monitor and evaluate debt to preclude a crisis? (c) We use stochastic optimal control/dynamic programming to derive an optimal debt. The deviation of the actual from the optimal will serve as a Warning Signal of a crisis. (d) There is a correspondence between Hamilton-Jacobi-Bellman equation of Dynamic Programming and the static Mean-Variance (M-V) analysis in finance. A graphic analysis of $\mathrm{M}-\mathrm{V}$ is helpful to explain the implications of DP. This paper is an application of Fleming-Stein (2004), Fleming-Pang (2003), and is a generalization of the Merton model. The analysis in Fleming-Stein (2001) has been applied by Stein-Paladino (2001) to crises involving short-term debt.

An explicit example used in this paper is the US Agricultural debt crisis, because the empirical data correspond closely to the appropriate mathematical variables. Figure 1 plots three variables concerning the US agricultural sector: the ratio of interest payments/value added, equity = capital less debt, and the delinquency rate on loans to commercial banks. During the prosperous years 1972-80 land values rose and, using the capital gains as collateral, farmers incurred debt to buy more land which produced more capital gains. The boom generated by capital gains was unsustainable. From 1980-86, 
farm equity fell by by three standard deviations with a rise in bankruptcies and defaults on loans. The shaded area refers to the debt crisis. Using available information, what warning signals should have alerted the farm and banking sectors to the impending crisis?

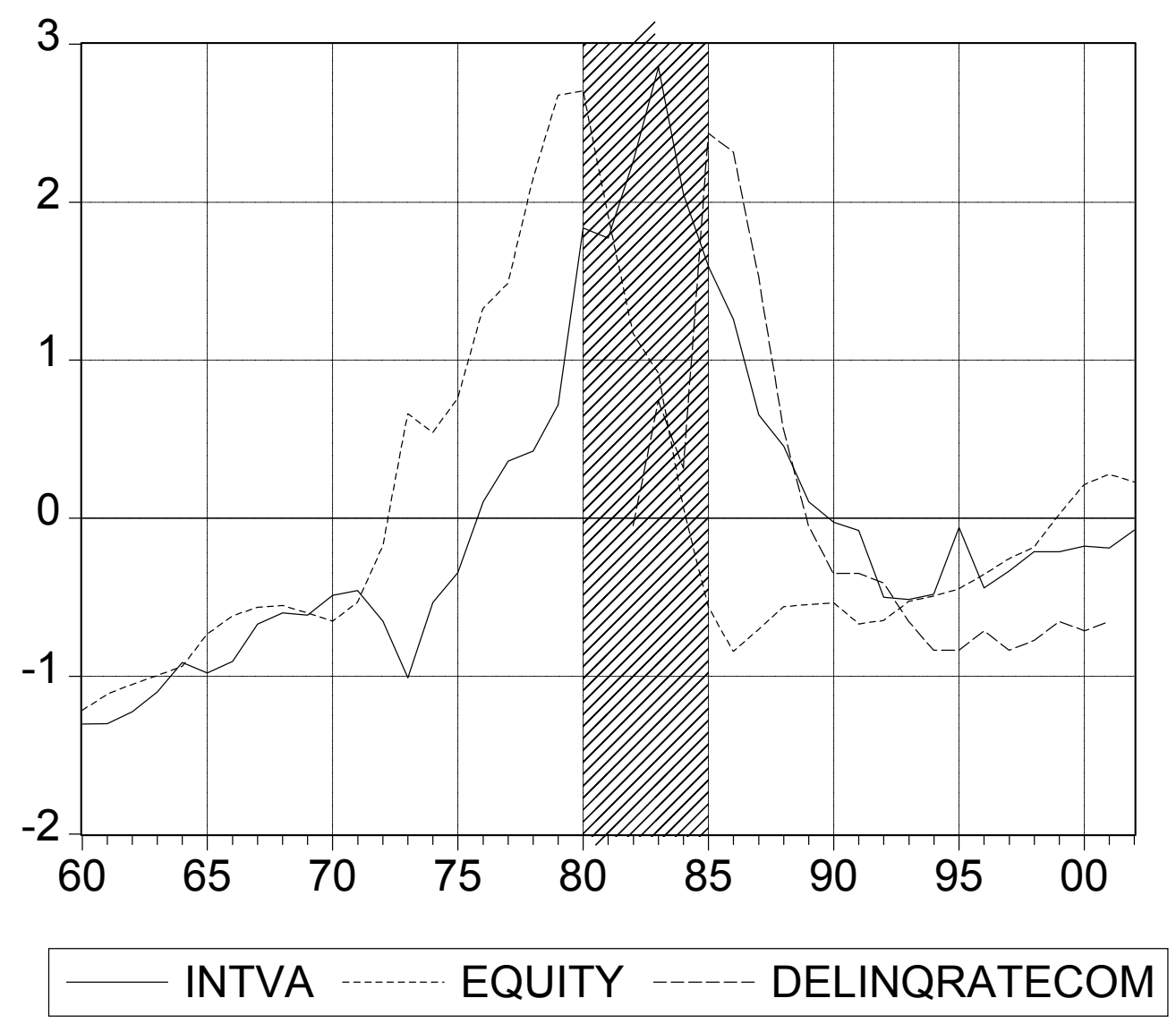

Figure 1. US Agriculture 1960 - 2002. INTVA = total interest payments/value added. EQUITY = assets - debt. DELINQRATECOM = delinquent farm loans to commercial banks, percentage of outstanding loans. Normalized variables: (variable - mean)/standard deviation.

\section{A Prototype model}

The model underlying the optimization is summarized in the equations in BOX 1 . The variables are real, measured in terms of goods produced. This benchmark model is sufficiently general to be applicable to almost any economy. The crucial features are that the fundamentals - the real return on capital and the variable real interest rate - are 
described by equations of Brownian motion. There is an expected return on capital but the actual return does not revert to a constant mean; and a similar situation exists for the real rate of interest. It is not possible to predict either the value of the return on capital or the interest rate. These equations are used to derive benchmarks of Rational Expectations (RE) optimal performance, conditional upon the real fundamentals: the real return on capital and the interest rate.

The actual debt deviates from the RE optimal because market participants base decisions upon anticipated capital gains that are not based upon these fundamentals. The unsustainable capital gains resulting from these anticipations generate speculative bubbles, like the dot.com in the US and the real estate boom in South-East Asia. The deviation between the actual and the optimal debt is a bubble that bursts when subjected to shocks. In part 5 below, we explain the farm debt crisis and provide warning signals.

The performance criterion to be maximized is the expected present value of the utility of consumption, equation (1). The maximum value is $\mathrm{V}(\mathrm{X})$, where $\mathrm{X}$ is the initial net worth. The utility function selected is HARA, equation (1a) where risk aversion is $(1-\gamma)>0, \gamma \neq 0$. The HARA utility function has two great advantages. First, it implies that we may focus upon ratios, such as consumption/net worth $\mathrm{c}=\mathrm{C} / \mathrm{X}$, debt/net worth $\mathrm{f}=$ $\mathrm{L} / \mathrm{X}$ and capital/net worth $\mathrm{k}=\mathrm{K} / \mathrm{X}$. Second: the HARA assumption lowers the dimension of the dynamical system, and the model can be solved analytically. Otherwise, the DP model must solved using numerical values and a computer. When $\gamma=0$, risk aversion is $(1-\gamma)=1$, and the utility function is (1b) the logarithmic function. An infinite time horizon is selected with an arbitrary discount rate of $\delta>0$. The effective length of the horizon is inversely related to the discount rate. A high discount rate implies a short horizon. If $\gamma<0$, there is no mathematical need to have a discount rate. 
BOX 1.

EQUATIONS OF THE STOCHASTIC GROWTH MODEL

$(1) \mathrm{V}(\mathrm{X})=\max _{c, \mathrm{f}} \mathrm{E}_{\mathrm{w}}\left\{\int_{0}^{\infty} \mathrm{U}(\mathrm{C}(\mathrm{t})) \mathrm{e}^{-\delta \mathrm{t}} \mathrm{dt}\right\}$

(1a) $\mathrm{U}(\mathrm{C})=(1 / \gamma) \mathrm{C}_{\mathrm{t}}^{\gamma}, \gamma<1, \gamma \neq 0$; (1b) $\mathrm{U}(\mathrm{t})=\ln \mathrm{C}_{\mathrm{t}}, \gamma=0, \quad \mathrm{C}=$ consumption

(2a) $\mathrm{dL}_{\mathrm{t}}=\mathrm{r}_{\mathrm{t}} \mathrm{L}_{\mathrm{t}} \mathrm{dt}+\left(\mathrm{C}_{\mathrm{t}}+\mathrm{I}_{\mathrm{t}}-\mathrm{Y}_{\mathrm{t}}\right) \mathrm{dt} \quad \mathrm{L}=\mathrm{debt}, \mathrm{f}=\mathrm{L} / \mathrm{X}$

(2b) $\mathrm{C}_{\mathrm{t}} \mathrm{dt}=\mathrm{Y}_{\mathrm{t}} \mathrm{dt}-\mathrm{r}_{\mathrm{t}} \mathrm{L}_{\mathrm{t}} \mathrm{dt}-\mathrm{I}_{\mathrm{t}} \mathrm{dt}+\mathrm{dL}_{\mathrm{t}}>0$

$\mathrm{c}=\mathrm{C} / \mathrm{X}$

(3) $\mathrm{K}_{\mathrm{t}}=\mathrm{P}_{\mathrm{t}} \mathrm{N}_{\mathrm{t}} \quad \mathrm{K}=$ capital, $\mathrm{Y}=$ value added

(4) $\mathrm{Y}_{\mathrm{t}} \mathrm{dt} / \mathrm{P}_{\mathrm{t}} \mathrm{N}_{\mathrm{t}}=\mathrm{b}_{\mathrm{t}} \mathrm{dt}=\mathrm{b} d \mathrm{dt}+\sigma_{\mathrm{b}} \mathrm{dw}_{\mathrm{b}}, \mathrm{dw}_{\mathrm{b}}=\varepsilon_{\mathrm{b}} \sqrt{d t}_{\mathrm{dt}} \varepsilon_{\mathrm{b}} \sim \mathrm{N}(0,1)$ iid

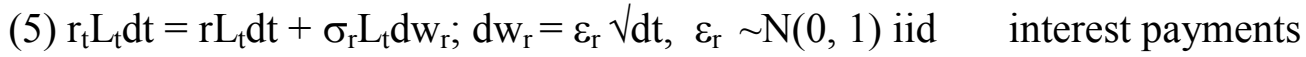

(5a) $\mathrm{L}_{\mathrm{t}}<\mathrm{hR}_{0} \mathrm{e}^{\eta t}$ lending constraint

(6) $\mathrm{E}\left(\varepsilon_{\mathrm{b}} \varepsilon_{\mathrm{r}}\right)=\rho, 1 \geq \rho \geq-1$.

(7) $\mathrm{dP}_{\mathrm{t}} / \mathrm{P}_{\mathrm{t}}=\mu \mathrm{dt}+\sigma_{\mathrm{p}} \mathrm{dw}_{\mathrm{p}}$ $\mathrm{P}=$ relative price of "land" $\mathrm{N}$

(7a) $\left.\mathrm{E}\left(\mathrm{dw}_{\mathrm{p}}, \mathrm{dw}_{\mathrm{b}}\right)\right)=0, \mathrm{E}\left(\mathrm{dw}_{\mathrm{p}}, \mathrm{dw}_{\mathrm{r}}\right)=0$

(8) $\mathrm{X}_{\mathrm{t}}=\mathrm{K}_{\mathrm{t}}-\mathrm{L}_{\mathrm{t}}=\mathrm{P}_{\mathrm{t}} \mathrm{N}_{\mathrm{t}}-\mathrm{L}_{\mathrm{t}}$ net worth $=$ equity

Equations (2a) and (2b) are the same. In (2a), the change in the debt $\mathrm{dL}_{\mathrm{t}}$ is the sum of the debt service $r_{t} L_{t}$ at interest rate $r_{t}$, plus consumption $C_{t}$ plus investment $I_{t}$ less income $\mathrm{Y}_{\mathrm{t}}$, over a period of length $\mathrm{dt}$. Equation $(2 \mathrm{~b})$ puts consumption on the left hand side. It is income less debt service less investment over the period plus new borrowing. For an economy, the sum of value added is GDP or income, denoted $\mathrm{Y}_{\mathrm{t}}$.

The production function is equations (3)-(4). Equation (3) states that capital $\mathrm{K}_{\mathrm{t}}$ is the product of a physical quantity $\mathrm{N}_{\mathrm{t}}$, "land", times the $\mathrm{P}_{\mathrm{t}}$ relative price of land/price of output. Equation (4) states that the productivity of capital, ratio $b_{t} d t=Y_{t} d t / K_{t}$ of gross value added to capital, is described by a stochastic process. The productivity of capital is the sum of a deterministic term $b$ dt plus a stochastic term $\sigma_{\mathrm{b}} \mathrm{dw}_{\mathrm{b}}$. Call $b$ the mean return on investment. The stochastic part of the growth of value added term $\sigma_{b} d w_{b}$ results from changes in prices of output relative to the purchased inputs of materials, physical productivity such as output/acre, and variations in demand. 
Equation (5) describes the stochastic servicing of the debt $r_{t} L_{t}$ over the short period dt. The real rate of interest over the short period $r_{t} d t$ is the sum of a deterministic term - the mean $\mathrm{r} d \mathrm{t}$ - plus a stochastic term, which has a variance $\sigma_{\mathrm{r}}^{2} \mathrm{dt}$ over the period. The stochastic part results from variations in monetary policy, the business cycle or, when an external debt in denominated in foreign currency, from changes in the exchange rate. The demand for loans by the entire agricultural sector is $\mathrm{L}_{\mathrm{t}}$. Constraint (5a) states that $\mathrm{L}_{\mathrm{t}}$ cannot exceed the loans that the banking system is willing to supply. The latter is a multiple $h>0$ of the reserves $R_{0} e^{\eta t}$ which grow at exogenous rate $\eta$. This constraint is important in explaining in section (5.2) below why bubbles burst and debt crises occur.

Each disturbance, to either the return on investment or to the real rate of interest, is time independent. Equation (6) states that the two disturbances, to the growth rate and to the interest rate, may be correlated, either positively or negatively. This correlation occurs by matching up one variation in $d_{\mathrm{b}}$ with one in $\mathrm{dw}_{\mathrm{r}}$.

Figure 2 graphs the two basic stochastic variables in the farm sector. The measured return per annum on real farm assets $b_{t}=$ real gross value added/real farm assets is denoted GVACAP; and the interest rate per annum $r_{t}=$ interest expense/farm debt is denoted INTDEB. Neither variable reverts to a constant mean. The correlation between them switches between positive and negative.

Net worth or equity $\mathrm{X}_{\mathrm{t}}$, equation (8) is defined as capital $\mathrm{K}_{\mathrm{t}}$, from (3), less debt $\mathrm{L}_{\mathrm{t}}$. We constrain the optimization to the case where net worth $X(t)>0$. This constraint excludes "Ponzi schemes", where the economy borrows to service the debt ad infinitum. 


$$
\begin{aligned}
& \text { GVAPCAP }=\mathrm{b}(\mathrm{t})=\text { return } \\
& \text { INTDEB }=\mathrm{r}(\mathrm{t})=\text { interest rate }
\end{aligned}
$$

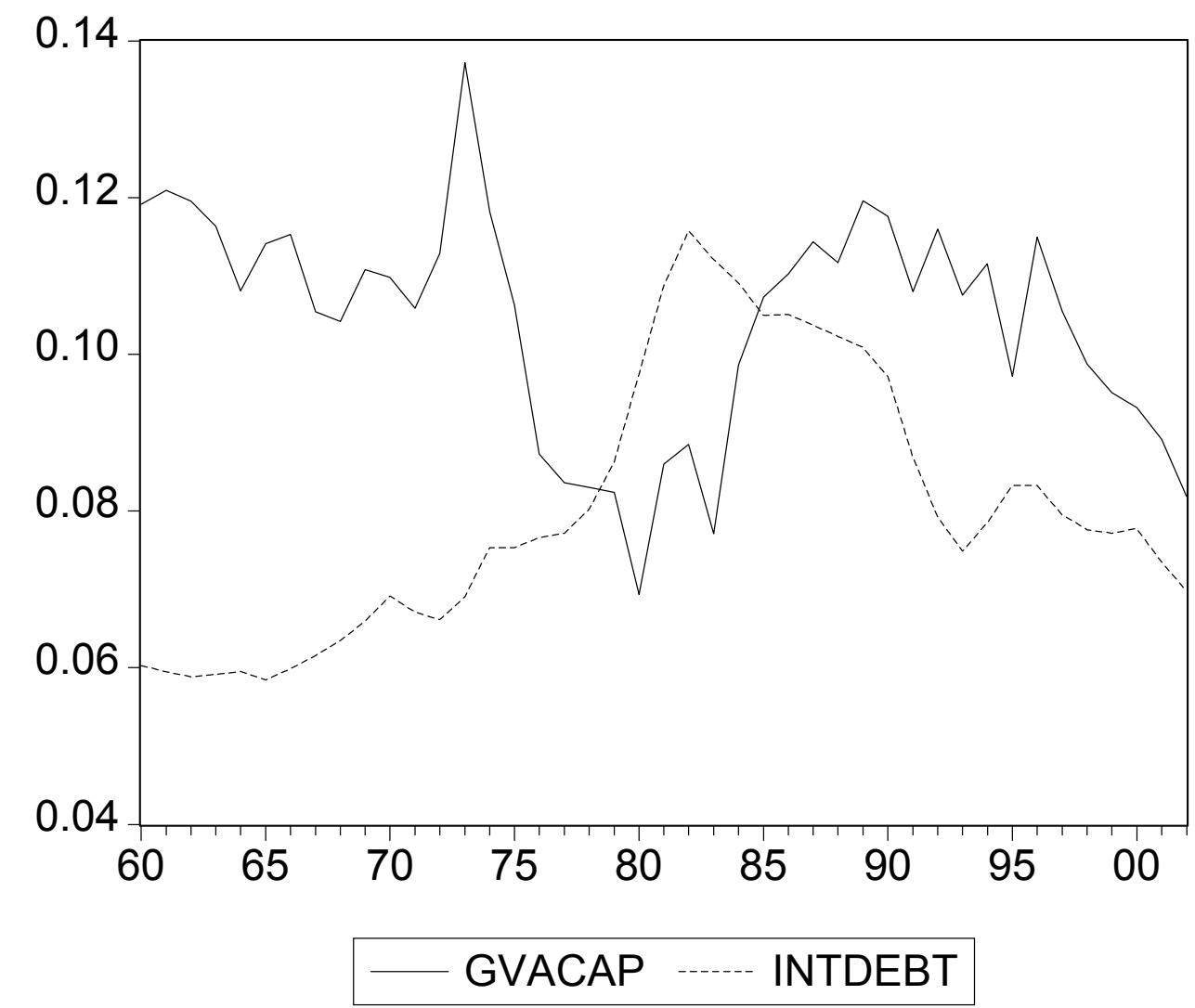

Figure 2. U.S. Farm sector. Return $=b_{t}=$ gross value added/value farm assets $=$ GVACAP. Interest rate $=r_{t}=$ interest expenses $/$ debt $=$ INTDEBT

The change in the value of assets $d K_{t}=d\left(P_{t} K_{t}\right)$ is equation (9). The first term $P_{t} d_{t}=I_{t} d t$ is investment at market prices, and the second term $\left(N_{t} P_{t}\right)\left(d P_{t} / P_{t}\right)$ is the capital gain (or loss) resulting from the rise (fall) in the price of the physical asset - $\mathrm{N}_{\mathrm{t}}$ called "land" - relative to the price of output.

(9) $\mathrm{dK}_{\mathrm{t}}=\mathrm{P}_{\mathrm{t}} \mathrm{dN}_{\mathrm{t}}+\left(\mathrm{N}_{\mathrm{t}} \mathrm{P}_{\mathrm{t}}\right)\left(\mathrm{dP}_{\mathrm{t}} / \mathrm{P}_{\mathrm{t}}\right)=\mathrm{I}_{\mathrm{t}} \mathrm{dt}+\mathrm{K}_{\mathrm{t}}\left(\mathrm{dP}_{\mathrm{t}} / \mathrm{P}_{\mathrm{t}}\right)$

In many debt crises - such as US agriculture, South-East Asia, or the dot.com stocks - there is a "bubble", defined as the case where the capital gains equation (7) are independent of the movements of the fundamentals $b_{t}$ and $r_{t}$. 
The market assumes that there is an upward trend $\mu>0$ in the relative price of "land", plus a Brownian motion term $\sigma_{\mathrm{p}} \mathrm{dw}_{\mathrm{p}}$. Both the Brownian motion $(\mathrm{BM})$ term $\sigma_{\mathrm{p}} \mathrm{dw}_{\mathrm{p}}$ and the trend term $\mu$ are independent of the other two BM terms in BOX 1, as described by equation (7a). In the case where there are "rational expectations" (RE), the market price of the asset will be closely linked to the fundamentals $b_{t}$ and $r_{t}$ and $\mu=0$. Our standard of optimal performance is the rational expectations case.

We have assumed that the return $b_{t}=Y_{t} d t / P_{t} N_{t}=Y_{t} d t / K_{t}=$ real gross value added/real value of assets is described by stochastic process equation (4), which is graphed as return GVACAP in figure 2. This formulation was selected because data are available for $\mathrm{Y}$ and $\mathrm{K}=\mathrm{PN}$, and $\mathrm{Y} / \mathrm{K}$ can be described by Brownian motion. On the other hand, Fleming and Pang (2003) assume that the return real gross value added/acre $=\mathrm{Y}_{\mathrm{t}} \mathrm{dt}$ $/ \mathrm{N}_{\mathrm{t}}$ is described by a stochastic process. In the RE case, both forms are identical, but the results differ in the case where $\mu>0$.

We show below that the optimization based upon $\mu>0$ leads to an unsustainable situation - a debt crisis. The deviation between the debt/net worth held in case where $\mu>$ 0 and the debt/net worth held in the case of rational expectations case $\mu=0$ provides us with Warning Signals of a debt crisis.

\section{Dynamic Programming Solution}

In this section we derive the dynamic programming solution for the optimal debt. Then it is shown how the inter-temporal dynamic programming $D P$ solution can be given a mean-variance $M-V$ interpretation. We then compare the optimal market debt when $\mu>$ 0 with the rational expectations RE solution when $\mu=0$.

The state variable is net worth $\mathrm{X}(\mathrm{t})$ defined in equation (8). It is capital $\mathrm{K}_{\mathrm{t}}$ less $\mathrm{L}_{\mathrm{t}}$ debt. The change in net worth is equation (10).

(10) $d X_{t}=d K_{t}-d L_{t}$

Derive equation (11) by using (9) for $\mathrm{dK}_{t}$ and (2a) for $\mathrm{dL}_{\mathrm{t}}$. The HARA function implies that consumption is proportional to net worth $\mathrm{C}_{\mathrm{t}}=\mathrm{cX}_{\mathrm{t}}$ and the debt is also proportional to net worth $\mathrm{L}_{\mathrm{t}}=\mathrm{fX}_{\mathrm{t}}$, (Fleming-Stein, 2004). The ratio $\mathrm{f}=\mathrm{L} / \mathrm{X}$ is debt/net worth. From (8), 
capital/net worth $\mathrm{k}_{\mathrm{t}}=\mathrm{K}_{\mathrm{t}} / \mathrm{X}_{\mathrm{t}}=1+\mathrm{f}_{\mathrm{t}} \geq 0$. Equation (11) is the stochastic differential equation. The first set of terms in brackets is deterministic and the second is stochastic. (11) $\mathrm{dX}_{\mathrm{t}} / \mathrm{X}_{\mathrm{t}}=[(\mathrm{b}-\mathrm{c})+(\mathrm{b}-\mathrm{r}) \mathrm{f}+(1+\mathrm{f}) \mu] \mathrm{dt}+\left[(1+\mathrm{f}) \sigma_{\mathrm{b}} \mathrm{dw}_{\mathrm{b}}-\mathrm{f}_{\mathrm{r}} \mathrm{dw}_{\mathrm{r}}+(1+\mathrm{f}) \sigma_{\mathrm{p}} \mathrm{dw} \mathrm{w}_{\mathrm{p}}\right]$

There are two controls, $\mathrm{u}=(\mathrm{f}, \mathrm{c})$. One control is $\mathrm{c}=\mathrm{C}_{\mathrm{t}} / \mathrm{X}_{\mathrm{t}}>0$ the consumption ratio. The second control is the debt ratio $f=L_{t} / X_{t}>-1$. A negative debt is net financial assets. It is assumed that the debt can be varied instantly and with no cost. This assumption is too strong and will be relaxed in subsequent research. The optimization (1) is subject to the dynamic equation (11) and to the constraints $C_{t}>0, X_{t}>0$.

Given the nature of the uncertainty, the controller cannot anticipate the future. The admissible controls are chosen using any information known up to time t. We therefore consider the controls that enter as feedback functions of the state $\mathrm{X}_{\mathrm{t}}$. The Hamilton-Jacobi-Bellman dynamic programming equations (12a) and (12b) are based upon the dynamics of the change in net worth, equation (11). See Fleming-Soner (1992). (12a) $\delta \mathrm{V}(\mathrm{X})=\max _{\mathrm{u}}\left[\mathrm{G}^{\mathrm{u}} \mathrm{V}(\mathrm{X})+(1 / \gamma)(\mathrm{cX})^{\gamma}\right], \mathrm{u}=(\mathrm{f}, \mathrm{c}>0)$.

(12b) $\mathrm{G}^{\mathrm{u}} \mathrm{V}(\mathrm{X})=[(\mathrm{b}-\mathrm{c})+(\mathrm{b}-\mathrm{r}) \mathrm{f}+(1+\mathrm{f}) \mu] \mathrm{XV}_{\mathrm{x}}$

$+(1 / 2)\left[\mathrm{f}^{2} \sigma_{\mathrm{r}}^{2}-2 \mathrm{f}(1+\mathrm{f}) \rho \sigma_{\mathrm{r}} \sigma_{\mathrm{b}}+(1+\mathrm{f})^{2}\left(\sigma_{\mathrm{b}}^{2}+\sigma_{\mathrm{p}}{ }^{2}\right)\right] \mathrm{X}^{2} \mathrm{~V}_{\mathrm{xx}}$

With the HARA utility function, we may write the value function as equation (13) where the constant $\mathrm{A}>0$ is to be determined from (12) and (13).

(13) $\mathrm{V}(\mathrm{X})=(\mathrm{A} / \gamma) \mathrm{X}^{\gamma}$

Using equation (13) and its derivatives in (12) we derive the DP equation (14) where $V^{*}(f, c)$ is defined in $(14 a, b, c)$.

(14) $\delta / \gamma=\max _{\mathrm{c}, \mathrm{f}}\left\{(1 / \gamma) \mathrm{c}^{\gamma} / \mathrm{A}+\mathrm{V}^{*}(\mathrm{f}, \mathrm{c})\right\}=\max _{\mathrm{c}, \mathrm{f}}\left\{(1 / \gamma) \mathrm{c}^{\gamma} / \mathrm{A}+\mathrm{M}(\mathrm{f}, \mathrm{c})-(1-\gamma) \mathrm{R}(\mathrm{f})\right\}$

$(14 a) V^{*}(f, c)=[M(f, c)-(1-\gamma) R(f)]$

(14b) $\mathrm{M}(\mathrm{f}, \mathrm{c})=[(\mathrm{b}-\mathrm{c})+(\mathrm{b}-\mathrm{r}) \mathrm{f}+(1+\mathrm{f}) \mu]$

$(14 \mathrm{c}) \mathrm{R}(\mathrm{f})=(1 / 2)\left[\mathrm{f}^{2} \sigma_{\mathrm{r}}^{2}-2 \mathrm{f}(1+\mathrm{f}) \rho \sigma_{\mathrm{r}} \sigma_{\mathrm{b}}+(1+\mathrm{f})^{2}\left(\sigma_{\mathrm{b}}^{2}+\sigma_{\mathrm{p}}^{2}\right)\right]$

The optimal debt/equity $\mathrm{f}$ is independent of the optimal consumption ratio. Define the market optimal debt/net worth ratio $f_{s}$ as one where $\mu>0$, when there are speculative capital gains, and define the Rational Expectations optimal $f^{*}$ as the special case where $\mu$ $=0$. The optimal ratio is stated in equation $(15)$, where $\sigma^{2}$ and $f(0)$ are defined in equations (15a), (15b) respectively. The ratio $\theta=\sigma_{\mathrm{r}} / \sigma_{\mathrm{b}}=$ standard deviations of the 
interest rate/ rate of return and ratio $\omega=\sigma_{\mathrm{p}} / \sigma_{\mathrm{b}}=$ standard deviations of the capital gain / rate of return. The market optimal debt/net worth ratio $f_{s}$ is a linear function of the expected net rate of return including the trend capital gain $(b+\mu-r)$. The expected real rate of return is $b$, and the expected real rate of interest is $(\mathrm{r}-\mu)$, where $\mu$ is the expected capital gain. As shown in section (5.2) below, the expected capital gain $\mu>0$ is unsustainable. The Rational expectations case sets $\mu=0$ and the optimal debt/net worth $\mathrm{f}^{*}$ is equation $(15-\mathrm{RE})$. The slope is the reciprocal of risk aversion $(1-\gamma)$ times risk $\sigma^{2}=$ variance $(b-r+d p / p)$ in equation (15a). The market debt/equity ratio $f_{s}$ will exceed the $\mathrm{RE}$ value $f^{*}$ if the expected trend inflation of asset prices $\mu>0$. Equation (15c) relates to constraint (5a). The demand for loans in the RE case $\mathrm{f}^{*} \mathrm{X}^{*}{ }_{\mathrm{t}}$, where $\mathrm{X}_{\mathrm{t}}{ }_{\mathrm{t}}$ is the net worth in the RE case, does not exceed the loans that banks are willing to make.

\begin{tabular}{|l|} 
Optimal debt/net worth $\mathrm{f}_{\mathrm{s}}$, Rational Expectations Case $\mathrm{f}^{*}$ \\
$(15) \mathrm{f}_{\mathrm{s}} \in \operatorname{argmax}[\mathrm{M}(\mathrm{f}, \mathrm{c})-(1-\gamma) \mathrm{R}(\mathrm{f})]=(\mathrm{b}+\mu-\mathrm{r}) /(1-\gamma) \sigma^{2}-\mathrm{f}(0)$ \\
$(15-\mathrm{RE}) \mathrm{f}^{*}=(\mathrm{b}-\mathrm{r}) /(1-\gamma) \sigma^{2}-\mathrm{f}(0)$ \\
$(15 \mathrm{a}) \sigma^{2}=\operatorname{var}(\mathrm{b}-\mathrm{r}+\mathrm{dp} / \mathrm{p})=\left(\sigma_{\mathrm{b}}^{2}+{\sigma_{\mathrm{r}}}^{2}+{\sigma_{\mathrm{p}}}^{2}-2 \rho \sigma_{\mathrm{b}} \sigma_{\mathrm{r}}\right)=\sigma_{\mathrm{b}}^{2}\left(1+\theta^{2}+\omega^{2}-2 \rho \theta\right)$ \\
$(15 \mathrm{~b}) \mathrm{f}(0)=\left(1+\omega^{2}-\rho \theta\right) /\left(1+\theta^{2}+\omega^{2}-2 \rho \theta\right)$ \\
$(15 \mathrm{c}) \mathrm{f}^{*} \mathrm{X}^{*}{ }_{\mathrm{t}}<\mathrm{h} \mathrm{R} \mathrm{R}_{0} \mathrm{e}^{\eta t}$
\end{tabular}

Equation (15) is a generalization of Merton's equation for the optimal ratio of risky assets/net worth. In Merton's model, the rate of interest is deterministic so $\theta=0$. There is only one component of the return on the risky asset, either $b_{t}$ or $d p_{t} / p_{t}$. Let it be $b_{t}$ so that $\omega=0$. (We could have chosen $d_{\mathrm{t}} / \mathrm{p}_{\mathrm{t}}$ and ignored $\mathrm{b}_{\mathrm{t}}$ ). Then, equation (15) for the optimal risky assets/net worth $\mathrm{k}=1+\mathrm{f}$ is equation (16). This is exactly Merton's equation.

(16) $\mathrm{k}^{*}=1+\mathrm{f}^{*}=(\mathrm{b}-\mathrm{r}) /(1-\gamma) \sigma_{\mathrm{b}}^{2}$

The meaning of the intercept term $\mathrm{f}(0)$ is discussed in the Mean-Variance section below.

\section{4. $A$ "mean-variance" (M-V) interpretation}

The Tobin-Markowitz mean variance (M-V) analysis is the cornerstone of much of the work in the field of investment/portfolio allocation analysis. It is extensively used in the agricultural finance literature to evaluate risk for agricultural firms. The M-V 
analysis is based upon a static two period model of portfolio choice between "safe" and "risky" assets, whose great virtue is that it yields clear and operational results. Our model in BOX 1 seems to be quite different. Growth is endogenous over an infinite horizon and there is risk on both the debt and on capital.

We show how the inter-temporal dynamic programming equations (14-15) can be given an interpretation in the traditional static two-period "mean-variance" portfolio choice model. The DP equation (14) can be expressed in several ways. The first term $\left[(1 / \gamma) \mathrm{c}^{\gamma} / \mathrm{A}\right]$ is the utility of present consumption, where term $\mathrm{A}>0$ is to be determined from the solution. The second term $\mathrm{V}^{*}(\mathrm{f}, \mathrm{c})$ can be interpreted in equation (14a) as Expected $M-V$ utility. It is equal to the Mean, equation (14b), less the product of risk aversion $(1-\gamma)>0$ and Risk, equation (14c). The Mean is the expected percentage change in net worth $\mathrm{E}\left(\mathrm{dX} \mathrm{X}_{\mathrm{t}} / \mathrm{dt}\right) / \mathrm{X}_{\mathrm{t}}$ in equation (11) if there were no risks. In the deterministic case, when one selects the controls $(\mathrm{c}, \mathrm{f})$ we know for certain that net worth $\mathrm{X}$ and consumption $\mathrm{cX}$ grow at rate $\mathrm{M}(\mathrm{f}, \mathrm{c})$. There are also stochastic components to the change in net worth. We must also consider the risk terms $R(f, c)=(1 / 2)$ var $\left[d_{t} / X_{t}\right]$, which is one half of the variance of the growth in net worth. Risk contains the control debt ratio $f$, variances and co-variances. Hence the DP equation (14) can be interpreted as (17). Maximize the sum of the utility of current consumption plus $\mathrm{V}^{*}=\mathrm{M}-\mathrm{V}$ expected utility: a linear combination of a mean $\mathrm{M}$ and $(1-\gamma) \mathrm{R}$ a risk $\mathrm{R}$ times positive risk aversion. (17) $\delta / \gamma=\max _{c, \mathrm{f}}\{$ utility current consumption $+[$ Mean - (risk aversion)(Risk)]\} Equation (17) shows that the maximization with respect to the optimal debt/net worth from the DP equation can be given a $M$-V interpretation, since debt is only in the $V^{*}$ term. A negative debt is a positive financial asset position. 


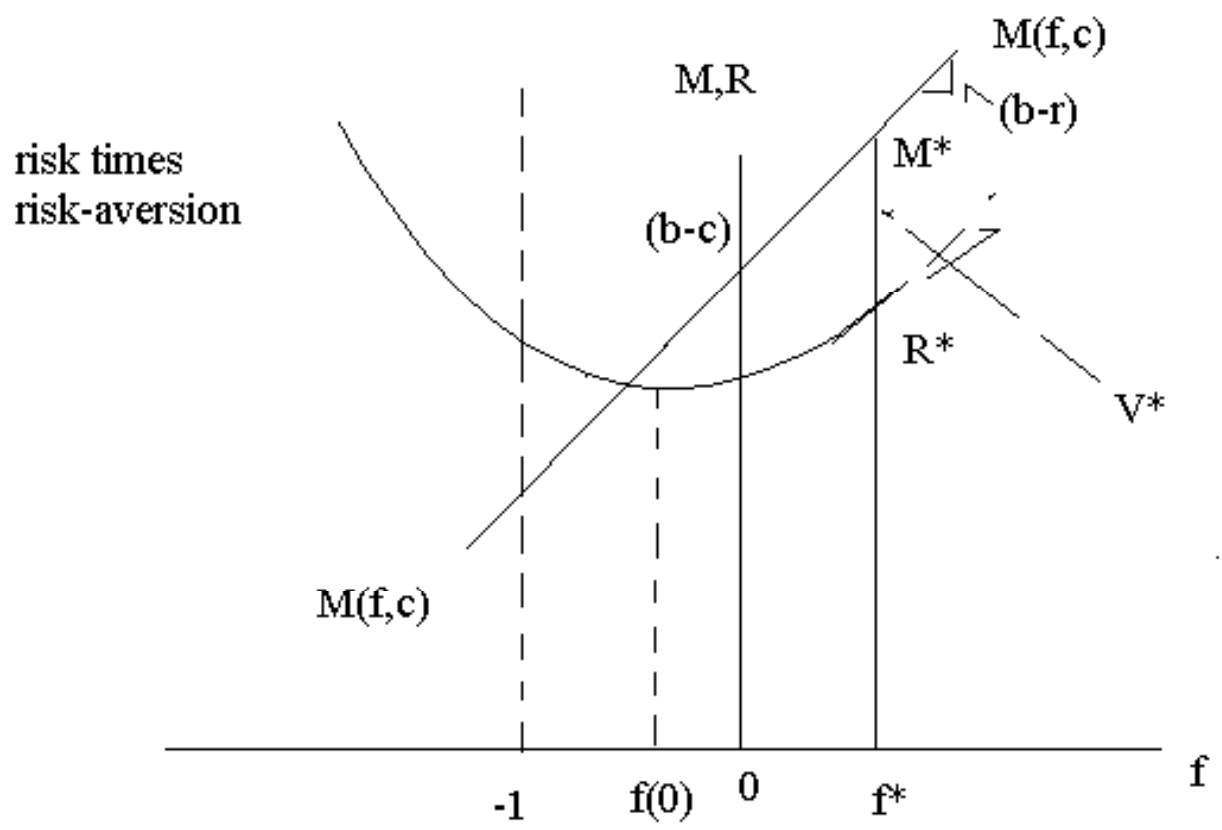

Figure 3. Mean-Variance Interpretation of the DP equation for optimal debt/net worth $\mathrm{f}^{*}$ in the Rational Expectations case, where $\mu=0$.

A graphic discussion of the determination of $\mathrm{f}^{*}$ the optimum debt/net worth is described in figure 3, for the Rational Expectations case where there is no expected speculative capital gains. The DP equation requires that we select a debt/net worth ratio f that maximizes the "mean-variance expected utility" $\mathrm{V}^{*}=\mathrm{M}(\mathrm{f}, \mathrm{c})-(1-\gamma) \mathrm{R}(\mathrm{f})$. The mean $\mathrm{M}(\mathrm{f}, \mathrm{c})$ is a linear function of $\mathrm{f}$ the debt/net worth. The slope of the Mean function $\mathrm{dM} / \mathrm{df}$ $=(b-r)$ is the expected return less the expected interest rate. Intercept $(b-c)$ is the expected return less the consumption ratio. Variations in the consumption ratio only affect the intercept and not the slope of the Mean function. Therefore optimal debt/net worth is independent of the consumption ratio.

The uncertainty concerns the risk R(f), which is a quadratic function of the $\mathrm{debt} /$ net worth, and is defined in equation (14c). In figure 3 quadratic risk function $\mathrm{R}(\mathrm{f})$ reaches a minimum at $f=f(0)$, which is equation (15b) - the intercept term in the optimal debt/equity equation (15). To minimize risk when $\mathrm{f}(0)<0$, the firm should be a creditor.

There is a big difference between the $\mathrm{M}-\mathrm{V}$ interpretation of the DP equation and the static two-period M-V analysis. For example, in the DP interpretation/ RE case 
denoted by asterisks, optimal debt $\mathrm{L}_{\mathrm{t}}{ }^{*}=\mathrm{f}^{*} \mathrm{X}^{*}{ }_{\mathrm{t}}$. Net worth $\mathrm{X}^{*}{ }_{\mathrm{t}}$ varies according to stochastic differential equation (11) when $\mu=0$. As $X^{*}{ }_{t}$ varies, the debt $L^{*}{ }_{t}$ must be varied instantaneously to maintain the ratio $\mathrm{f}^{*}$ to net worth $\mathrm{X}^{*}{ }_{\mathrm{t}}$. On the other hand, in static M-V analysis (Robison et al), a rise (decline) in net worth implies that, while holding constant the level of risky assets, the debt should be decreased (increased). Thus inter-temporal DP analysis can be given a $M$-V interpretation, but one cannot go from static M-V to inter-temporal optimization.

\section{Application to farm debt crisis}

\subsection{Accumulation of debt in the prosperous years}

An application of the DP technique to explain the US farm debt crisis of the early 1980s (see FDIC, 1997) may serve as a model how to monitor the debt of any country or region. The agricultural crisis has been selected because there are available data that closely correspond to the theoretical variables.

Agriculture flourished in the 1970s. Farm exports grew rapidly and along with the domestic inflation farm incomes reached all-time highs. These factors produced capital gains on farm assets. Credit was readily available. Real interest rates $(r-\mu)$ were low and farmers used the rising value of farm assets as collateral for loans. Farmers would purchase farm real estate with moderate down payments and, after the value of the newly purchased land increased, would use the increased equity to buy additional farm land with minimal downpayments. Higher levels of real estate debt were supplemented by debt to finance machinery and equipment. The speculation in land produced capital gains $\mu>0$ and raised $X$ the market value of equity. Figure 1 shows how the ratio of interest payments/value added $=$ INTVA $=$ debt burden, grew as the farm EQUITY rose. By 1979, the debt burden was almost 3 standard deviations higher than it was in 1973. Lenders were not concerned since equity rose by as much, due to the capital gains.

\subsection{Crisis: collapse of the bubble}

The bubble started to burst in 1979 and the depression continued through the decade of the 1980s. In the fall of 1979, the Federal Reserve undertook a restrictive monetary policy and interest rates $r_{\mathrm{t}}$ rose drastically. The resulting appreciation of the US 
dollar reduced foreign demand for US agricultural products. The decline in foreign demand was exacerbated by the debt crisis in the less developed countries. Farm exports declined by 40\% from 1981 to 1986, at a time when productive capacity had increased. The decline in demand is a decline in $b_{\mathrm{t}}$. Figure 1 shows how EQUITY fell from 1980-86 by about 3 standard deviations, and farm delinquency rates on commercial bank loans rose drastically. We contrast the Rational Expectations case $\mu=0$ with the market bubble $\mu>0$, and derive Warning Signals of an impending crisis.

Defaults will occur at time $\mathrm{T}$ when the economy cannot service the debts without a decline in consumption, described by equation (25), based upon (2a) above even when investment is zero. The key to the crisis or collapse of the bubble is that the interest payments are growing rapidly, there is a negative shock to the return on capital $b_{t}$, a positive shock to the interest rate $\mathrm{r}_{\mathrm{t}}$ and there is a constraint on new bank lending $\mathrm{dL}_{\mathrm{t}}$. (25) $\mathrm{C}_{\mathrm{T}} \mathrm{dt}=\left(\mathrm{b}_{\mathrm{T}} \mathrm{K}_{\mathrm{T}}-\mathrm{r}_{\mathrm{T}} \mathrm{f}_{\mathrm{s}} \mathrm{X}_{\mathrm{T}}\right)-\mathrm{I}_{\mathrm{T}}+\mathrm{dL}_{\mathrm{T}}$

As a result of the bubble $\mu>0$, the ratio of debt/net worth is $\mathrm{f}_{\mathrm{s}}$, net worth is $\mathrm{X}_{\mathrm{T}}$ and interest payments are $r_{T} L_{T}=r_{T} f_{S} X_{T}$. The cash flow at crisis time $T=1980$ is the first term in parentheses: value added $Y_{T}=b_{T} K_{T}$ less interest payments $r_{T} L_{T}=r_{T} f_{S} X_{T}$. At time $\mathrm{T}=1980$, there was a negative shock to the productivity of capital $\mathrm{b}_{\mathrm{T}}$, and a positive shock to the interest rate $\mathrm{r}_{\mathrm{T}}$, which produced a severe decline in cash flow. Consumption would fall unless the farmers obtain new loans $\mathrm{dL}_{\mathrm{T}}$ to service the debt. This Ponzi scheme will not last for long for the following reason.

The expectation of the debt $L_{t}=f_{s} X_{t}$ in the bubble case exceeds that in the Rational Expectations case (denoted by asterisks), since $f_{s}>f^{*}$ and $X>X^{*}$. When $\mu>0$, the expectation of the debt that would exist at time $T$ is $E\left(L_{T}\right)=f_{s} E\left[X_{T}\right]=f_{s} X_{0} \exp [((b$ $-c)+(b-r) f+(1+f) \mu) T]$. The expected net worth is derived from stochastic differential equation (11) using the proof in Øksendal, pp. 60-61.

The lending constraint is assumed to be satisfied in the RE case, equation (15c). However, when the bubble $\mu>0$ is significantly high, such that $\left((b-c)+(b-r) f_{s}+\right.$ $\left.\left(1+f_{s}\right) \mu\right)>\eta$, the lending constraint will eventually be violated. The bubble case is the left hand expression and the RE is the right hand expression.

$\left[E\left(L_{T}\right)=f_{s} E\left(X_{T}\right)\right]>h R_{0} e^{\eta T}>\left[E\left(L^{*} T\right)=f^{*} E\left(X^{*} T\right)\right]$ 
The banks/lenders are constrained to lend no more than multiple $h$ of their reserves which grow at rate $\eta$.As the speculative bubble continues, loans rise towards the maximum that the banks are willing to finance. The availability of funds for new loans declines, particularly when cash flows decline. Even though interest rates may not reflect it, banks decrease the availability of credit. The decline in the availability of new loans $\mathrm{dL}_{\mathrm{T}}$ means that the third term in (25) declines; and it may even turn negative. The decline in all three terms in (25) implies that: To service the debt, consumption must decline. This will lead to defaults and hence a debt crisis. This scenario also describes many of the major international debt crises.

\subsection{Warning Signals}

Warning signals WS will be based upon the difference between the actual debt/net worth and the sustainable RE optimal f*. Similarly, the WS will be the difference between the interest payments/value added and the RE optimal based upon f*.

We base our estimates of the means $b$ and $r$ upon available information. The US Department of Agriculture, Economic Research Service (ERS), Agricultural Income and Finance, Farm Income and Balance Sheet Indicators contains data for: $\mathrm{Y}_{\mathrm{t}}=$ value added, $\mathrm{K}_{\mathrm{t}}=$ value of farm assets $=$ capital, $\mathrm{L}_{\mathrm{t}}=$ debt, $\mathrm{r}_{\mathrm{t}} \mathrm{L}_{\mathrm{t}}=$ interest expenses, and $\left(\mathrm{K}_{\mathrm{t}}-\mathrm{L}_{\mathrm{t}}\right)=$ equity $=$ net worth, all measured in constant dollars on a base $1996=100$. The sample period is $1960-2002$.

The interest rate on the debt $r_{t}=$ INTDEB is a weighted average of the interest rates $r_{t} L_{t} / L_{t}$. Five-year moving averages of gross real value added/real capital $=$ $\mathrm{GVACAP}=\mathrm{Y}_{\mathrm{t}} / \mathrm{K}_{\mathrm{t}}$ and INTDEB from year T-5 to the present year $\mathrm{T}$, are used to estimate the means. The mean net return is a five year moving average of real gross value added/real farm assets less interest rate, denoted by $(b-r)_{5}$, measured as percent per annum. This variable is based upon available information. Both (b-r) $)_{5}$ and the variance of the net return are slowly changing over time.

Ideally, we would like our warning signal $\mathrm{WS}_{\mathrm{t}}$ to be the difference between the actual debt/net worth $=\mathrm{L}_{\mathrm{t}} / \mathrm{X}_{\mathrm{t}}$ and the RE optimum $\mathrm{f}^{*}$ in equation (15-RE). (27) $\mathrm{WS}_{\mathrm{t}}=\mathrm{L}_{\mathrm{t}} / \mathrm{X}_{\mathrm{t}}-\mathrm{f}_{\mathrm{t}}=\mathrm{L}_{\mathrm{t}} / \mathrm{X}_{\mathrm{t}}-\left[\mathrm{m}(\mathrm{b}-\mathrm{r})_{5}-\mathrm{f}(0)\right]$, where $\mathrm{m}=1 /(1-\gamma) \sigma^{2}$ As the difference increases, the debt burden $r_{t} L_{t} / Y_{t}$ rises and the probability of a debt 
crisis increases, see equation (26). The measure of risk aversion is arbitrary, and the variance differs among sub-periods. Therefore, we use two warning signals, evaluated when $\mathrm{m}=1 /(1-\gamma) \sigma^{2}=1$, and $\mathrm{f}(0)=0$. In $(28 \mathrm{a})$, we measure the deviation of the actual debt/equity ratio from the moving average of the net return. This is labeled WARNING. (28a) WARNING $=\mathrm{L}_{\mathrm{t}} / \mathrm{X}_{\mathrm{t}}-(\mathrm{b}-\mathrm{r})_{5}$

Warning signal WARNING2 in (28b) is the deviation of interest payments/value added $r_{t} L_{t} / Y_{t}$ from the moving average of the net return.

(28b) WARNING2 $=r_{t} L_{t} / Y_{t}-(b-r)_{5}$.

Both warning signals are graphed in figure 4, where the variables are normalized, (variable - mean)/standard deviation. Each warning signal is measured in units of standard deviations to facilitate a comparison and provide orders of magnitude. The normalization is why the evaluation at $\mathrm{m}=1$ and $\mathrm{f}(0)=0$ is not a problem.

The farm debt crisis occurred during the period 1980-88, the shaded area, when defaults and delinquency ratios rose drastically. On the basis of this figure we see the usefulness of the warning signals WS. From 1965-75, there were no warning signals - the "green light" was on. From 1973-77, the two WS rise by one standard deviation - the "amber light" is on. By 1979, the WS has risen to two standard deviations from 1975: the "red light" is on. In 1980, the crisis occurs.

From 1975-83 the 5-year moving average net return was declining, and from 1979-84 the actual net return was negative. The actual numbers are as follows.

$\begin{array}{llll} & \text { debt/equity } & \text { mean net return (b-r) } & \text { interest expense/value added } \\ 1975 & 20 \% & 4.55 \% & 11.8 \% \\ 1985 & 29.8 & -1.87 & 22.48\end{array}$

The optimal debt/equity ratio and interest expense/value added should have been declining rather than rising. Our analysis, based upon Dynamic programming, correctly predicts a debt crisis in the shaded region and correctly predicts tranquil periods pre-1979 and post 1990 . 


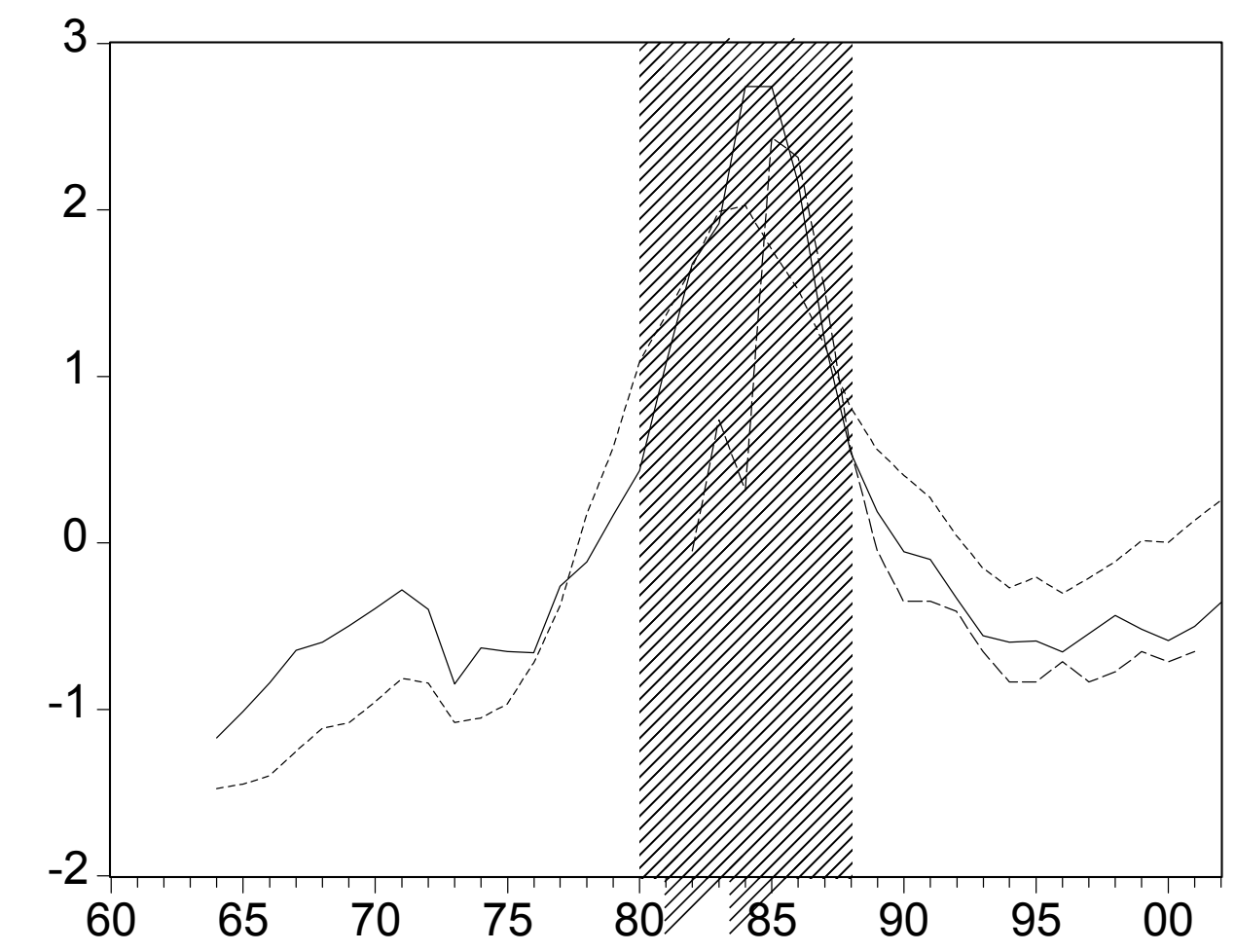

WARNING - WARNING2

Figure 4. WARNING $=$ debt/equity - retvaintd5 $=(\mathrm{L} / \mathrm{X})_{\mathrm{t}}-(\mathrm{b}-\mathrm{r})_{5}, \mathrm{WARNING} 2=$ interest payments/value added $r_{t} L_{t} / Y_{t}-(b-r){ }_{5}$, DELINQRATECOM $=$ delinquency rate on commercial bank loans for agriculture 


\section{REFERENCES}

Federal Deposit Insurance Corporation (FDIC,1997), An Examination of the Banking Crises of the 1980s and Early 1990s, History of the Eighties - Lessons for the Future, Banking and the Agricultural Problems of the 1980s, chapter 8.

Fleming, W. H. and Soner, H. M., (1992), Controlled Markov Processes and Viscosity Solutions, New York: Springer Verlag, Berlin, Heidelberg, New York.

Fleming, Wendell H. and Stein, Jerome L. (2004), Stochastic Optimal Control, International Finance and Debt, Journal of Banking and Finance, forthcoming.

Fleming, W. H., Stein, J.L., (2001), Stochastic Inter-temporal Optimization in Discrete Time, in Negishi,Takashi, Rama Ramachandran and Kazuo Mino (ed) Economic Theory, Dynamics and Markets: Essays in Honor of Ryuzo Sato, Kluwer, Boston.

Fleming, W. H. and T. Pang (2003), "A Stochastic Control Model of investment, production and consumption", Division of Applied Mathematics, Working Paper

Øksendal, B. (1995) Stochastic Differential Equations, Springer, Berlin, Heidelberg, New York

Robison, Lindon, Peter Barry and and William Burghardt (1987), Borrowing Behavior under Financial Risk by the Proprietary Firm, Western Jour. Agricultural Economics, 12

Stein, Jerome L. and Paladino, Giovanna (2001) Country Default Risk: An Empirical Assessment, Australian Economic Papers, 40, (4), December

U.S. Department of Agriculture, Economic Research Service, Agricultural Income and Finance, Farm Income and Balance Sheet Indicators (2002). 


\section{CESifo Working Paper Series}

(for full list see www.cesifo.de)

980 Vivek Ghosal, Firm and Establishment Volatility: The Role of Sunk Costs, Profit Uncertainty and Technological Change, July 2003

981 Christopher A. Pissarides, Unemployment in Britain: A European Success Story, July 2003

982 Wolfgang Buchholz, Richard Cornes, and Wolfgang Peters, On the Frequency of Interior Cournot-Nash Equilibria in a Public Good Economy, July 2003

983 Syed M. Ahsan and Panagiotis Tsigaris, Choice of Tax Base Revisited: Cash Flow vs. Prepayment Approaches to Consumption Taxation, July 2003

984 Campbell Leith and Jim Malley, A Sectoral Analysis of Price-Setting Behavior in US Manufacturing Industries, July 2003

985 Hyun Park and Apostolis Philippopoulos, Choosing Club Membership under Tax Competition and Free Riding, July 2003

986 Federico Etro, Globalization and Political Geography, July 2003

987 Dan Ariely, Axel Ockenfels and Alvin E. Roth, An Experimental Analysis of Ending Rules in Internet Auctions, July 2003

988 Paola Conconi and Carlo Perroni, Self-Enforcing International Agreements and Domestic Policy Credibility, July 2003

989 Charles B. Blankart and Christian Kirchner, The Deadlock of the EU Budget: An Economic Analysis of Ways In and Ways Out, July 2003

990 M. Hasham Pesaran and Allan Timmermann, Small Sample Properties of Forecasts from Autoregressive Models under Structural Breaks, July 2003

991 Hyun Park, Apostolis Philippopoulos and Vangelis Vassilatos, On the Optimal Size of Public Sector under Rent-Seeking competition from State Coffers, July 2003

992 Axel Ockenfels and Alvin E. Roth, Late and Multiple Bidding in Second Price Internet Auctions: Theory and Evidence Concerning Different Rules for Ending an Auction, July 2003

993 Pierre Salmon, The Assignment of Powers in an Open-ended European Union, July 2003

994 Louis N. Christofides and Chen Peng, Contract Duration and Indexation in a Period of Real and Nominal Uncertainty, July 2003 
995 M. Hashem Pesaran, Til Schuermann, Björn-Jakob Treutler, and Scott M. Weiner, Macroeconomic Dynamics and Credit Risk: A Global Perspective, July 2003

996 Massimo Bordignon and Sandro Brusco, On Enhanced Cooperation, July 2003

997 David F. Bradford, Addressing the Transfer-Pricing Problem in an Origin-Basis X Tax, July 2003

998 Daniel Gros, Who Needs Foreign Banks?, July 2003

999 Wolfram Merzyn and Heinrich W. Ursprung, Voter Support for Privatizing Education: Evidence on Self-Interest and Ideology, July 2003

1000 Jo Thori Lind, Fractionalization and the Size of Government, July 2003

1001 Daniel Friedman and Donald Wittman, Litigation with Symmetric Bargaining and TwoSided Incomplete Information, July 2003

1002 Matthew Clarke and Sardar M. N. Islam, Health Adjusted GDP (HAGDP) Measures of the Relationship Between Economic Growth, Health Outcomes and Social Welfare, July 2003

1003 Volker Grossmann, Contest for Attention in a Quality-Ladder Model of Endogenous Growth, August 2003

1004 Marcel Gérard and Joan Martens Weiner, Cross-Border Loss Offset and Formulary Apportionment: How do they affect multijurisdictional firm investment spending and interjurisdictional tax competition?, August 2003

1005 Burkhard Heer, Nonsuperneutrality of Money in the Sidrauski Model with Heterogeous Agents, August 2003

1006 V. Anton Muscatelli, Piergiovanna Natale, and Patrizio Tirelli, A Simple and Flexible Alternative to the Stability and Growth Pact Deficit Ceilings. Is it at hand?, August 2003

1007 Reto Foellmi and Josef Zweimüller, Inequality and Economic Growth: European Versus U.S. Experiences, August 2003

1008 James S. Costain and Michael Reiter, Business Cycles, Unemployment Insurance, and the Calibration of Matching Models, August 2003

1009 Marco Runkel, Optimal Contest Design when the Designer's Payoff Depends on Competitive Balance, August 2003

1010 Donald O. Parsons, Torben Tranaes and Helene Bie Lilleør, Voluntary Public Unemployment Insurance, August 2003

1011 Rüdiger Pethig and Andreas Wagener, Profit Tax Competition and Formula Apportionment, August 2003 
1012 Johan Willner, Privatisation and Public Ownership in Finland, August 2003

1013 Seppo Kari and Jouko Ylä-Liedenpohja, Taxation and Valuation of International Real Investments, August 2003

1014 James Heckman, Rosa Matzkin and Lars Nesheim, Simulation and Estimation of Hedonic Models, August 2003

1015 Biswa N. Bhattacharyay, Towards a Macro-Prudential Leading Indicators Framework for Monitoring Financial Vulnerability, August 2003

1016 J. Stephen Ferris and Stanley L. Winer, Searching for Keynes: With Application to Canada, 1870-2000, August 2003

1017 Massimo Bordignon, Luca Colombo and Umberto Galmarini, Fiscal Federalism and Endogenous Lobbies' Formation, August 2003

1018 Annette Alstadsæter, The Dual Income Tax and Firms' Income Shifting through the Choice of Organizational Form and Real Capital Investments, August 2003

1019 Peter Fredriksson and Bertil Holmlund, Optimal Unemployment Insurance Design: Time Limits, Monitoring, or Workfare?, August 2003

1020 Kashif S. Mansori, Following in their Footsteps: Comparing Interest Parity Conditions in Central European Economies to the Euro Countries, August 2003

1021 Christoph Borgmann and Matthias Heidler, Demographics and Volatile Social Security Wealth: Political Risks of Benefit Rule Changes in Germany, August 2003

1022 Kjell Erik Lommerud, Bjørn Sandvik and Odd Rune Staume, Good Jobs, Bad Jobs and Redistribution, August 2003

1023 Patrick Karl O'Brien, The Governance of Globalization: The Political Economy of Anglo-American Hegemony, 1793-2003, September 2003

1024 Antonio Ciccone and Giovanni Peri, Skills' Substitutability and Technological Progress: U.S. States 1950-1990, September 2003

1025 Bjørn Sandvik, Optimal Taxation and Normalisations, September 2003

1026 Massimo Bordignon and Gilberto Turati, Bailing Out Expectations and Health Expenditure in Italy, September 2003

1027 José A. Herce, Namkee Ahn, Ricard Génova, and Joaquín Pereira, Bio-Demographic and Health Aspects of Ageing in the EU, September 2003

1028 John Komlos and Marieluise Baur, From the Tallest to (One of) the Fattest: The Enigmatic Fate of the American Population in the $20^{\text {th }}$ Century, September 2003 
1029 Stefan Napel and Mika Widgrén, Bargaining and Distribution of Power in the EU's Conciliation Committee, September 2003

1030 Kai Li and Dale J. Poirier, Relationship Between Maternal Behavior During Pregnancy, Birth Outcome, and Early Childhood Development: An Exploratory Study, September 2003

1031 Ivar Ekeland, James J. Heckman, and Lars Nesheim, Identifcation and Estimation of Hedonic Models, September 2003

1032 Kjetil Bjorvatn and Alexander W. Cappelen, Decentralization and the Fate of Minorities, September 2003

1033 Lars-Erik Borge and Jørn Rattsø, The Relationships Between Costs and User Charges: The Case of a Norwegian Utility Service, September 2003

1034 Maureen Were and Nancy N. Nafula, An Assessment of the Impact of HIV/AIDS on Economic Growth: The Case of Kenya, September 2003

1035 A. Lans Bovenberg, Tax Policy and Labor Market Performance, September 2003

1036 Peter Birch Sørensen, Neutral Taxation of Shareholder Income: A Norwegian Tax Reform Proposal, September 2003

1037 Roberta Dessi and Sheilagh Ogilvie, Social Capital and Collusion: The Case of Merchant Guilds, September 2003

1038 Alessandra Casarico and Carlo Devillanova, Capital-skill Complementarity and the Redistributive Effects of Social Security Reform, September 2003

1039 Assaf Razin and Efraim Sadka, Privatizing Social Security Under Balanced-Budget Constraints: A Political-Economy Approach, September 2003

1040 Michele Moretto, Paolo M. Panteghini, and Carlo Scarpa, Investment Size and Firm's Value under Profit Sharing Regulation, September 2003

1041 A. Lans Bovenberg and Peter Birch Sørensen, Improving the Equity-Efficiency Tradeoff: Mandatory Savings Accounts for Social Insurance, September 2003

1042 Bas van Aarle, Harry Garretsen, and Florence Huart, Transatlantic Monetary and Fiscal Policy Interaction, September 2003

1043 Jerome L. Stein, Stochastic Optimal Control Modeling of Debt Crises, September 2003 